\title{
吸引生検による膀胼癌リンパ節転移の診断
}

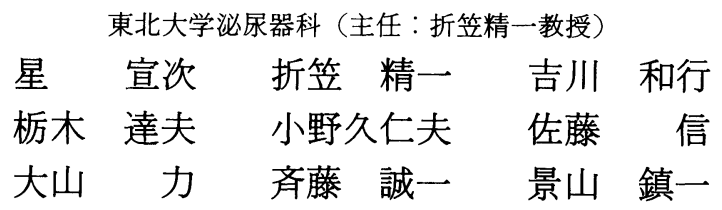

\section{ASPIRATION BIOPSY OF REGIONAL LYMPH NODE IN BLADDER CANCER}

\author{
Senji Hoshi, Seiichi Orikasa, Kazuyuki Yoshikawa, Tatsuo Tochigi, Kunio Ono, \\ Makoto Satoh, Chikara Ohyama, Seiichi Saitoh and Shizuichi Kageyama \\ Department of Urology, Tohoku University School of Medicine \\ (Director: Prof. S. Orikasa)
}

Percutaneous transabdominal fine needle aspiration biopsy (FNAB) of the pelvic and retroperitoneal lymph nodes was performed in 116 patients with bladder cancer. Metastasis to the regional lymph nodes was determined by this method in 21 patients. FNAB was positive in 10 of 12 patients having unequivocally positive or highly suspicious lymphogram, and in 11 of 104 patients (11\%) having normal lymphogram. The results of FNAB were compared to the finding of lymph node dissection (LND) in 51 patients. FNAB and LND were negative in 43 patients and positive in 5 . Two patients were FNAB negative but LND positive, and the remaining one case was FNAB positive but LND negative. The correlation between cytological diagnosis of FNAB and histological diagnosis of LND was 94 per cent. The survival rate of the cases of FNAB positive and lymphography negative was significantly higher than that of lymphography positive $(p<0.01)$. The metastasic site of 5 cases with bladder cancer who are alive now without disease after more than 3 years was under the common iliac node and the number of the involved nodes was within 3 .

Key words: bladder cancer, lymph node meastases, fine needle aspiration biopsy

\begin{abstract}
要旨：膀朕癌例116例に両足背よりのリンパ管造影後，細針による経腹的な骨盤・後腹膜リンパ節の吸引 生検を行った。リンパ管造影では12例が画像診断上陽性であり，吸引生検による細胞診では12例中10例 が陽性であった。リンパ管造影陰性であった104例中11例（11\%) が吸引生検陽性であった。 51 例に膀脱 全摘術，リンパ節郭清術を行った。吸引生検による細胞診と郭清による組織診がともに陽性は 5 例，共 に陰性は43例で，1例は吸引生検が陽性で郭清が陰性，2 例は吸引生検が陰性で郭清が陽性であった。 吸引生検と郭清の一致率は $94 \%$ であった。遠隔転移を認めない症例で, リンパ管造影陰性で吸引生検陽 性例の生存率は，リンパ管造影陽性例に比べ有意に $(\mathrm{p}<0.01)$ 高かった。リンパ節転移陽性 5 例が 3 年 以上再発なく生存中である。それらの症例のリンパ節転移部位は総腸骨領域以下であり，転移リンパ節 の数は 3 個以内であった。 キーワード：膀胱癌, リンパ節転移, リンパ節吸引生検
\end{abstract}

\section{緒 言}

教室では1982年より尿路性器悪性腫瘍のリンパ節転 移の有無を知る目的で, 経腹的リンパ節吸引生検 (FNAB)による細胞診を行って来た ${ }^{122}$. その症例数は 1889年12月までで277例あり,そのうち65例のリンパ節 より悪性細胞を検出した。その内訳は膀胱癌21例，前
立腺癌19例などである(表 1).今回は本法を行った膀 脱癌例について検討した。

\section{対象および方法}

対象はFNABを行った膀胼癌116例である。あらか じめリンパ管造影を行ったレ線写真に左図のごとく番 号をつけ，その番号順にリンパ節の吸引を行った。症 
表 1 骨盤・後腹膜リンパ節吸引生検施行症例

\begin{tabular}{|c|c|c|c|c|}
\hline & \multirow{2}{*}{ 症例数 } & \multirow{2}{*}{$\begin{array}{l}\text { 細胞診 } \\
\text { 陽性例 }\end{array}$} & \multicolumn{2}{|c|}{ 画 像 診 断 } \\
\hline & & & $(+)$ & $(-)$ \\
\hline 膀脱癌 & 116 & 21 & 10 & 11 \\
\hline 腎盂・尿管癌 & 20 & 6 & 4 & 2 \\
\hline 前立腺癌 & 53 & 19 & 11 & 8 \\
\hline 腎癌 & 25 & 5 & 0 & 5 \\
\hline 精巣腫瘍 & 42 & 7 & 4 & 3 \\
\hline その他 & 21 & 7 & 5 & 2 \\
\hline 計 & 277 & 65 & 34 & 31 \\
\hline
\end{tabular}

1989. 12.31

例によるが，3１2個，平均7.6個のリンパ節を吸引し た．右図はNo.2のリンパ節を穿刺しているところで ある(図 1 )。硬膜外麻酔下に患者をレ線透視台に仰卧 させる. 直径 $0.6 \mathrm{~mm}$ の23gauge, $20 \mathrm{~cm}$ の細針を用いて レ線透視下に経腹的にリンパ節を穿刺し，吸引ピスト ル， extension tubeを用いて陰圧をかけて吸引する。 その後陰圧を解除し穿刺針を拔去する(図 2 )。穿刺吸 引液はスライドグラスに塗洙し，パパニコロウーない しギムザ染色を行う.な怙本検査の所要時間は約 30 分, $\mathrm{X}$ 線の透視時間は約15分である。

\section{結 果}

膀胱癌例116例にリンパ管造影, FNAB を行った(表 2 ). 耪胱癌の stage, grade 分類は膀胱癌取扱い規約 に従った(表 3 )。リンパ管造影では，12例が画像診断 上陽性であった（このうち 8 例が CT でリンパ節転移 が指摘された)。FNABによる細胞診では12例中10例 に陽性所見を得た。このらち 3 例に膀脂全摘, リンパ 節郭清を行い組織学的にリンパ節転移を確認した。 2 例は充分な細胞が採取されずFNAB 陰性であった。 またりンパ管造影陰性であった104例中11例（11\%) が FNAB 陽性であった。 この11例中 3 例が膀胱全摘術, リンパ節郭清術がなされたが，2 例は細胞診と組織診 が一致した。1例は細胞診が陽性で組織診が陰性であ りこの症例は微小なリンパ節転移のため，たをたま 組織学的に検出できなかったためと考穴られた。また FNAB 陰性の93例中 45 例が膀脱全摘術, リンパ節郭清 術がなされ43例は郭清でも陰性であったが，2 例が細 胞診が陰性で組織診が陽性であった。 この 2 例中 1 例 は外腸骨リンパ節の微小転移例であり，も51例は右 内腸骨，左外腸骨のそれぞれ1個の転移であった。 FNAB と郭清の一致率は $94 \%$ であった。

Kaplan-Meier 法による累積生存率を示した。遠隔

図 1 あらかじめリンパ管造影を行ったレ線写真に左図のごとく番号をつけ，その番 号順にリンパ節の吸引を行った。右㘠はNo. 2のリンパ節を穿刺しているところで ある。
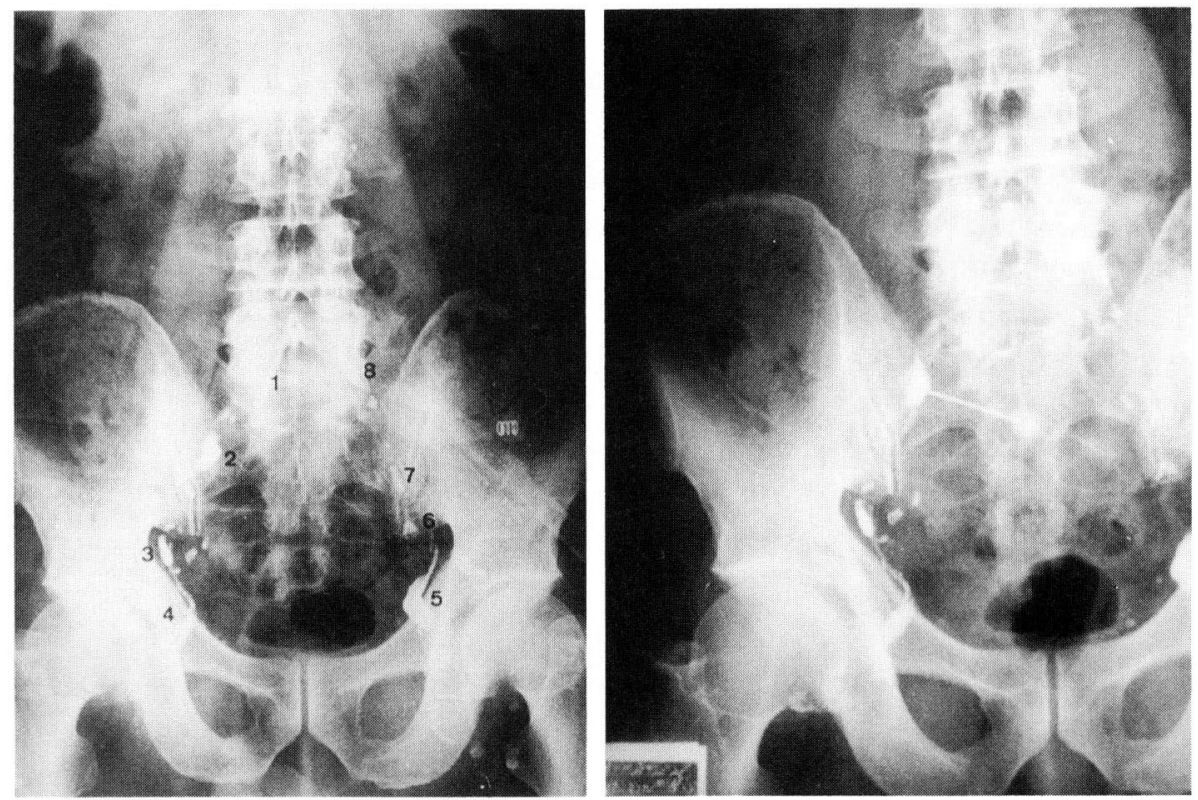
表 2 膀胼癌のリンパ管造影, リンパ節吸引生検, リンパ節郭清の関係

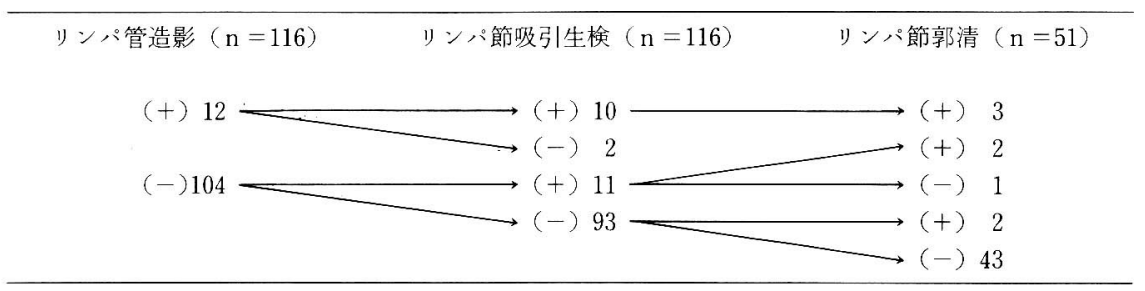

吸引生検と郭清の一致率：48/51=94\%

図 2 硬膜外麻酔下に患者をレ線透視台に仰臥させ る. 直径 $0.6 \mathrm{~mm}$ の23gauge, $20 \mathrm{~cm}$ の細針を用いてレ 線透視下に経腹的にリンパ節を穿刺し, 吸引ピスト ル, extension tube を用いて陰圧をかけて吸引す る. その後陰圧を解除し穿刺針を抜去する。
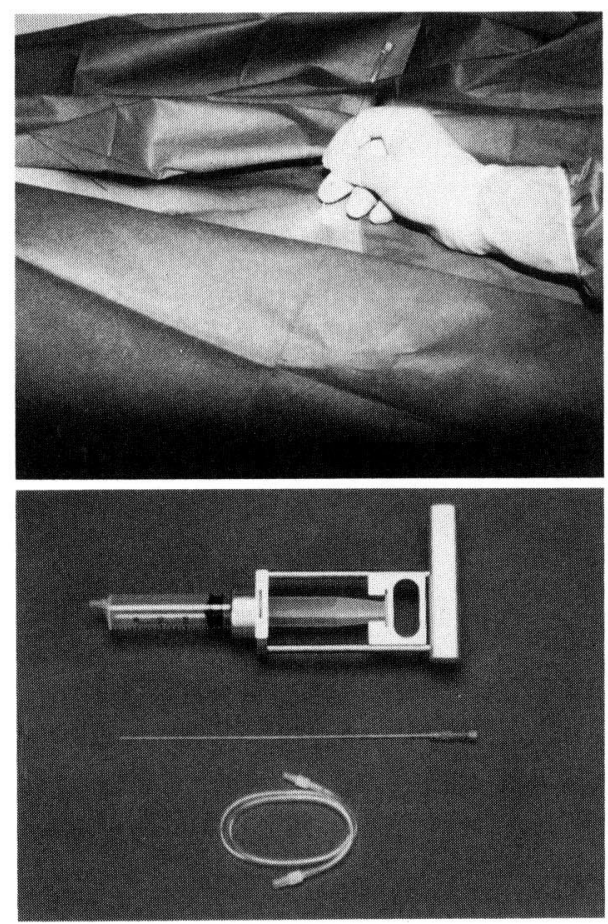

転移を認めない例でリンパ管造影陰性で FNAB 陽性 の11例の 5 年生存率は $45 \%$ であり,リンパ管造影陽性, FNAB 陽性の 10 例は 9 例が 1 年以内に癌死しており 1 例が 14 力 NED で生存中である。この両者間には, 一般化 Wil-coxon 検定で $1 \%$ 以下の危険率で有意差 が認められた（図 3 ).

リンパ節転移を有する膀胱癌の長期生存例を 5 例経 験している(表 4)。これらの例のリンパ節転移部位は
表 3 リンパ節吸引生検を抗こなった膀胱癌の Grade こ Stage の関係

\begin{tabular}{c|c|l|c|c|c}
\hline & G 1 & G2 & G 3 & SCC & Total \\
\hline Tis & & & 6 & & 6 \\
Ta & & 10 & 1 & & 11 \\
T1 & 4 & 22 & 13 & & 39 \\
T2 & & $11(1)$ & $5(3)$ & & $16(4)$ \\
T3 & & 5 & $17(5)$ & $3(1)$ & $25(6)$ \\
T4 & & $4(2)$ & $12(8)$ & $3(1)$ & $19(11)$ \\
\hline Total & 4 & $52(3)$ & $54(16)$ & $6(2)$ & $116(21)$ \\
\hline ( ) リンパ節吸引生検陽珄例
\end{tabular}

図 3 膀胱癌例の生存率

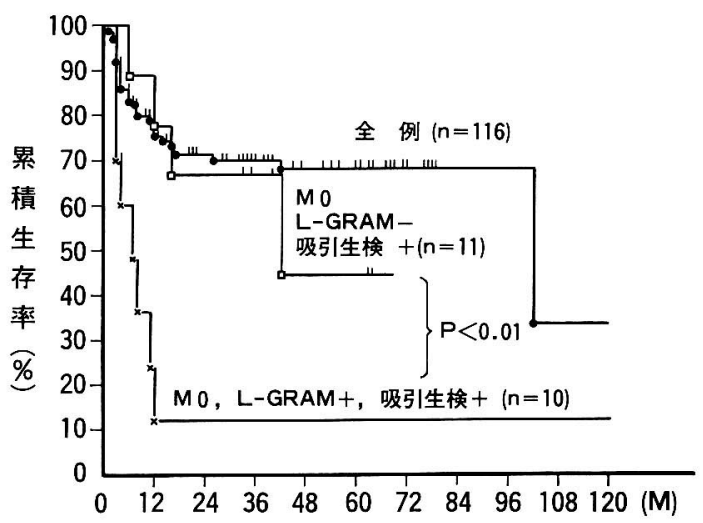

総腸骨領域以下に限られており，転移リンパ節の数も 3 個以内であった。なお 5 例中リンパ管造影陽性例は 症例 4 の 1 例のみであった。

次ぎに症例を供覧する

症例 1 は FNAB 陰性であったが, リンパ節郭清時 の迅速診断にて右外腸骨リンパ節に転移を認めたた め, 膀胼全摘は行わ寸゙, 尿路変更のみを行い, CDDP, $\mathrm{ADM}$ の静脈内投与と $60 \mathrm{~Gy}$ の放射線照射を行ったと 
表 4 リンパ節転移を有する膀胖癌長期生存例

\begin{tabular}{|c|c|c|c|c|c|c|c|}
\hline & \multicolumn{2}{|c|}{ リンパ節転移 } & \multirow{2}{*}{ 手術 } & \multirow{2}{*}{ 化療 } & \multirow{2}{*}{ 照射 } & \multirow{2}{*}{\multicolumn{2}{|c|}{ 生存期間 (M) }} \\
\hline & 部位 & 数 & & & & & \\
\hline $\begin{array}{c}\text { 1. 相 } \bigcirc \text { 元 } \bigcirc \\
70 \mathrm{M}\end{array}$ & r. eI & 1 ケ & $\begin{array}{l}\text { 尿変 } \\
\text { 郭清 }\end{array}$ & + & $60 \mathrm{~Gy}$ & 84 & 癌なし \\
\hline 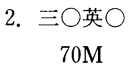 & $\begin{array}{l}\text { 1. iI } \\
\text { 1. eI }\end{array}$ & $\begin{array}{l}2 \\
1\end{array}$ & $\begin{array}{l}\text { 全摘 } \\
\text { 郭清 }\end{array}$ & + & 40 & 68 & 癌なし \\
\hline $\begin{array}{c}\text { 3. 細 } \bigcirc \text { 清 } \bigcirc \\
62 \mathrm{M}\end{array}$ & $\begin{array}{l}\text { r. iI } \\
\text { 1. eI }\end{array}$ & $\begin{array}{l}1 \\
1\end{array}$ & $\begin{array}{l}\text { 全摘 } \\
\text { 郭清 }\end{array}$ & + & - & 40 & 癌なし \\
\hline $\begin{array}{c}\text { 4. 熊 } \bigcirc \text { 誠 } \bigcirc \\
55 \mathrm{M}\end{array}$ & $\begin{array}{l}\text { r. eI } \\
\text { 1. eI } \\
\text { 1. cI }\end{array}$ & $\begin{array}{l}1 \\
1 \\
1\end{array}$ & - & + & 18 & 44 & 癌なし \\
\hline $\begin{array}{c}5 . \text { 星○茂○ } \\
53 \mathrm{M}\end{array}$ & 1. eI & 2 & $\begin{array}{l}\text { 全摘 } \\
\text { 郭清 }\end{array}$ & + & - & 36 & 癌なし \\
\hline
\end{tabular}

$\mathrm{r}:$ right, 1 : left, iI : internal Iliac, eI : external Iliac,

cI : common Iliac

ころ膀朕腫痬は消失した。 7 年経過した現在, 膀胱腫 瘍の再発，遠隔転移はいずれも認めていない。

症例 2 は膀胼の左側壁に広範な浸潤性の腫瘍を認 め, FNAB にて左外腸骨リンパ節より癌細胞を検出し たため, CDDP, ADMを，内腸骨動脈内に注入したの ち膀胱全摘術，リンパ節郭清術を行った．左内外腸骨 領域に 3 個のリンパ節転移を認めた。病理組織診断は pT3aN2M0，中分化型の扁平上皮癌であった。そこで 化学療法の追加と全骨盤腔に40Gy の放射線照射を 行った. 化学療法の総投与量は, CDDP 226mg, ADM $40 \mathrm{mg}$, PEP $34 \mathrm{mg}$ であった. 本例も5 年経過した現在 腫瘍の再発を認めていない。

症例 4 は膀胱のほぼ全腔を占める腫瘍で，両側の水 腎，水尿管を認めた。リンパ管造影では左外腸骨リン パ節の 1 個の一部に欠損像を認めた. FNAB では左右 の外腸骨，左総腸骨リンパ節それぞれ 1 個より悪性細 胞を検出した。本症例は膀胱全摘術を拒否されたため， 経尿道的に膀胱腫瘍を切除し，化学療法（total dose CDDP 1,075mg, PEP 70mg, ADM 68mg, MTX 136 mg，VP-16 150mg）を主に骨盤動脈内に注入し，また 骨盤腔に放射線照射を $18 \mathrm{~Gy}$ 行った。 3 年 5 カ月経過 したが，膀胱内再発や遠隔転移は認めていない。

症例 5 はFNAB にて左外腸骨リンパ節に転移を認 めた. CDDP と ADM の左内腸骨動脈内注入療法を 2 クール行った後, 膀胼全摘術とリンパ節郭清術を行っ た。病理組織学的には膀胼癌は完全に消失していたが, 2 個の左外腸骨リンパ節転移を認めた。そこでさらに 化学療法を 2 クール行い退院した。術後 3 年経過した
が局所再発や遠隔転移は認めない。

\section{考察}

両足背よりのリンパ管造影は骨盤・後腹膜臓器の悪 性腫瘍のリンパ節転移の診断に用いられてきたが, false positive, false negative が多いために頻用され ていないのが現状であろう.一方 Zornoza ら³゙，膀脱 癌例で造影されたリンパ節を透視下に穿刺吸引したリ ンパ節転移を細胞診にて診断して以来，後腹膜・骨盤 リンパ節吸引生検法は泌尿器科領域でも欧米でさかん に実施されるよらになってきだ)。経膜的リンパ節吸 引生検法は，あらかじめリンパ管造影を行う必要があ り，この意味でリンパ管造影にあらたな意義をもたら したと言える。

骨盤内リンパ節転移の診断に CT，MR が試みられ ている ${ }^{5) 6}$ がな拓信頼性に欠けている。内腸骨，閉鎖り ンパ節が造影されにくい欠点はあるが，現時点では 1 2 $\mathrm{cm}$ の骨盤内リンパ節転移を適確に診断する方法 はリンパ管造影以外にない，自検例でも CT でリンパ 節転移ありとしたのは 8 例のみで，これらの例はすべ てリンパ管造影陽性であった。一方，FNAB の有用性 は高い。リンパ管造影陽性の 12 例中，確実に細胞が吸 引された10例は細胞診陽性であり，残りの 2 例は，十 分な細胞が吸引されなかったためである。これは技術 的な問題と考えられるが，リンパ節より細胞を吸引す る技術は年々向上している2). リンパ管造影が陰性で あった症例のらち11例 (11\%) が FNAB 陽性であった ことは，臨床的には極めて重大である。これらの症例 は，臨床的にはリンパ節微小転移例と考学られる。 FNAB はリンパ節の微小転移の検出の可能性を秘め ている. 一方膀胱癌の stage と FNAB の陽性例の関 係を見ると (表 3 )，T1以下の症例には FNAB 陽性例 は見られなかった。T2以上の症例での FNAB 陽性率 は35\% (21/60) であり，浸潤性膀胖癌を疑われる症例 にはリンパ管造影, FNAB を行ってみる意義があると 思われる。

Wajsman $5^{7)}$ は FNAB 陽性例の膀胼癌例に対して のリンパ筋郭清は予後を改善せず, radical な手術を行 らょりもむしろ, 化学療法, 放射線療法を行らべきと 述べている。一方 CDDPを含む化学療法の進歩ととも に, 膀胼癌に対しても術前に化学療法（ないし放射線 療法)を行らいわゆる neo-adjuvant 療法が試みられる ようになって来ている ${ }^{8)}$. 微小転移の想定されれる症 例ではまず化学療法を行い, 原発巣と微小転移を縮小 あるいは消退させたうえで手術療法を加えるものであ 
る。そういった意味でリンパ節転移を手術前に確認す ることは, 大変重要である.

neo-adjuvant 療法として骨盤動脈内注入療法によ るよい成績が報告されている ${ }^{910)}$ ，そしてその後摘出 した膀胼に腫瘍の残存を認めなかった例，あるいは組 織学的に化学療法が著明に奏功した例の予後が特に良 かったとの報告が見られる ${ }^{9) \sim 11}$ 。我々も浸潤性膀胼癌 に対して CDDP，ADM を主薬剂として骨盤内動脈注 入療法を $2 \sim 3$ クール行っている. その効果判定には, 我々がさきに報告した膀胱癌の全層生検を行ってい る. 全層生検法 ${ }^{12) 133}$ は膀胼癌の正確な深達度判定法々 して,あるいは neo-adjuvant 療法を正しく評価する上 で大変有用である。

リンパ節転移と予後について Smith ら ${ }^{14}$ は，134例 の骨盤内リンパ節転移を有する症例を N1：総腸骨動 脈分岐部以下に 1 個の転移を認める, $\mathrm{N} 2 ：$ 総腸骨動脈 分岐部以下の同側に 2 個以上の転移を認める, N3：両 側に転移を認めるが，転移部位は，総腸骨動脈分岐部 以下にとどまる, N4：総腸骨動脈分岐部以上に転移を 認める, の 4 群に分類し, 各群の粗 5 年生存率を検討 した. その結果 N1が $17 \%, \mathrm{~N} 2$ \& N3が $5 \%$, N4が $0 \%$ であったと報告, 転移リンパ節の数と転移の範囲によ

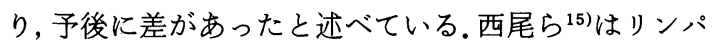
節転移を認める 29 例を, 転移リンパ節数 3 個以内 17 例 と 4 個以上 12 例の 2 群に分け検討した。 3 個以内の 17 例中再発は 7 例 (41\%)， 7 例が NED で生存し， 5 年 以上の生存例 3 例, 2 例は 3 年 5 年で生存中という. 一方転移リンパ節 4 個以上の 12 例では, 再発率 $80 \%$ (10 例) と高く，骨盤内再発も多く，予後は極めて不良で， 3 年以上の長期生存例は認めていない。このように転 移リンパ節の数と部位が膀胼癌例の予後を左右するこ とがうかがえる．自験例のリンパ節転移陽性の 21 例に ついてみると, FNAB のみ陽性の11例はリンパ管造影 も陽性であった10例にくらべあきらかに予後は良かっ た。臨床的なリンパ節微小転移の段階では集学的治療 が奏効し，このような予後の差が出たと考兄られる。 我々はリンパ節転移が骨盤腔を超えるような膀胱癌例 に対しては原則的には膀胼全摘は行わずに, 化学療法, 放射線療法を優先している。リンパ節転移が骨盤内に 限局し, その数も少ない症例に対しては, 抗癌剤の骨 盤動脈内注入療法ないし放射線照射を行ってから膀胱 全摘術（あるいは膀胱部分切除術）を行っている.

リンパ節吸引生検の合併症としては, 血管の穿刺に よる出血, 腸の穿刺による腹膜炎, 転移リンパ節穿刺
による腫瘍の播種などが考えられるが, 277例の経験で は治療を必要とする合併症の発生をみた症例は 1 例も 経験していない。しかし, 今後も慎重に経過の観察が 必要と思われる。

\section{結 語}

膀胱癌の骨盤内リンパ節穿刺細胞診は, リンパ節転 移の検出に有用である。リンパ管造影で指摘できない リンパ節転移もある程度検出できる。リンパ節穿刺細 胞診とこれまで発表してきた膀胱壁の全層生検法の併 用により，正確な膀胱癌の staging，化学療法後の術前 の評価が可能となり，より綿密な治療計画を立てるこ とができるようになった。

\section{文献}

1）星 宣次, 相馬文彦, 栃木達夫, 吉川和行, 折笠精 一, 松田尚太郎 : 経腹的後腹膜リンパ節吸引生検 法. 泌尿紀要，29，1411-1417，1983.

2). 三浦 $ゥ$ 子, 石岡国春, 木村伯子, 佐藤 泰, 富樫 明美, 三浦敏也, 長谷川清美, 星 宣次, 川合厚子 : 泌尿器癌症例における経腹的後腹膜リンパ節穿刺 吸引細胞診。日臨細胞誌，26，968-973，1987.

3) Zornoza, J., Wallance, S., Goldstein, H.M., Lukeman, J.M. and Jing, B. : Transperitoneal percutaneous retroperitoneal lymphnode aspiration biopsy. Radiology, 122, 111-115, 1977.

4) Chagnon, S., Cochang-Priollet, B., Gzaeil, M., Jacquenod, P., Roger, B., Boccon-Gibod, L. and Blery, M. : Pelvic cancer : Staging of 139 cases with lymphography and fine-needle aspiration biopsy. Radiology, 173, 103-106, 1989.

5) Salo, J.O., Kivisaari, L., Rannikko, S. and Lehtonen, T.: The value of CT in detecting pelvic lymph node metastases in cases of bladder and prostate carcinoma. Scand. J. Urol. Nephrol., 20, 261-265, 1986.

6) Amendola, M.A., Glaze, G.M., Grossman, H.B., Aisen, A.M. and Francis, I.R.: Staging of bladder carcinoma: MRI-CT-surgical correlation. AJR, 146, 1179-1183, 1986.

7) Wajsman, Z., Gamarra, M., Park, J.J., Beckley, S. and Pontes, J.E. : Transabdominal fine needle aspiration of retroperitoneal lymph nodes in staging of genitourinary tract cancer (correlation with lymphography and lymph node dissection findings). J. Urol., 128, 1238-1240, 1982.

8）垣添忠生：膀脱癌の surgical neo-adjuvant 療法 の進歩 Surgical neo-adjuvant 㞠法とは一その現 状一。泌尿器外科, 2, 543-549, 1989.

9) Galetti, T.P., Pontes, E., Montie, J., Medenorp, S.V, and Bukowski, R.: Neoadjuvant intra- 
arterial chemotherapy in the treatment of advanced transitional cell carcinoma of the bladder: Results and followup. J. Urol., 142, 1211-1215, 1989.

10) Kakizaki, H., Suzuki, H., Kubota, Y., Numazawa, K. and Suzuki, K.: Preoperative oneshot intra-arterial infusion chemotherapy for bladder cancer. Cancer Chemothea. Phamacol., 20, 15-19, 1987.

11）蓮田良浩, 長田幸男, 上原和隆：膀胱癌における膀 腅全摘術前集学的治療による病理組織学的反応の 検討。西日泌尿，51，1449-1453，1989.

12）星 宣次, 折笠精一, 吉川和行, 栃木達夫, 沼田 功, 小野久仁夫, 加藤正和, 松田尚太郎：針生検に
よる膀胱腫瘍の全層標本を用いた膀胖癌の浸潤度 診断. 1. Surecut 針による生検. 日泌尿会誌, 77, 923-929, 1986.

13）栃木達夫, 吉川和行, 星 宣次, 折笠精一, 小野久 云夫，加藤正和：経皮的膀胱壁全層生検による膀 脱癌深達度診断の試み。日泌尿会誌, 77, $1578-1584,1986$.

14) Smith, J.A. Jr. and Whitmore, W.F. Jr. : Regional lymph node metastasis from bladder cancer. J. Urol., 126, 591-593, 1981.

15）西尾添規, 松本恵一, 大谷幹伸, 垣添忠生：膀胼移 行上皮癌に対する根治的膀胱全摘除術の治療成 績。日泌尿会誌，77，79-86，1986。

(1990年 6 月 5 日受理) 